В. Д. Карлов ${ }^{1}$, О. Л. Кузнєцов ${ }^{1}$, А. М. Артеменко ${ }^{2}$ А. Д. Карлов ${ }^{1}$

${ }^{1}$ Харківський національний університет Повітряних Сил імені. Івана Кожедуба, Харків, Україна

${ }^{2}$ Генеральний штаб Збройних Сил України, Київ, Україна

\title{
ПОСТАНОВКА ЗАДАЧІ ОПТИМАЛЬНОГО ВИМІРЮВАННЯ ДАЛЬНОСТІ ДО ЦІЛІ В КОГЕРЕНТНО-ІМПУЛЬСНИЙ РЛС ПРИ ВРАХУВАННІ ФАЗОВИХ СПОТВОРЕНЬ РАДІОЛОКАЦІЙНОГО СИГНАЛУ
}

\begin{abstract}
У статті розглянуто питання аналізу можливостей забезпечення заданої дальності дії РЛС, здатної здійснювати радіолокаційне спостереження малопомітних, малорозмірних та маневруючих цілей. Обгрунтована доцільність використання когерентної пачки радіоімпульсів для забезпечення необхідної дальності виявлення із заданими показниками якості. Надано порівняльний аналіз можливостей використання поодинокого і пачкового радіосигналів. Доведена необхідність врахування корельованих фазових флуктуацій радіоімпульсів прийнятої пачки при вимірюванні дальності до цілі. Вважається, що фазові флуктуації розподілені за нормальним законом с нульовим середнім, а їх кореляція убуває зі збільшенням інтервалу між радіоімпульсами пачки за експоненціальним або знакозмінним законами. На вхід приймального пристрою РЛС надходять відбиті від цілей сигнали на фоні некорельованого гаусівського шуму. Розгляд проводиться для моделі сигналу з випадковою амплітудою та початковою фазою. Оцінювання часу запізнення радіолокаційного сигналу здійснюється за критерієм максимуму натурального логарифма відношення правдоподібності, усередненого по усім можливим значенням випадкових неінформативних параметрів. В явному вигляді отримано вираз нормованої функції розузгодження когерентної пачки за наявністю фазових флуктуацій їі радіоімпульсів. Врахування фазових флуктуацій радіоімпульсів прийнятої пачки при вимірюванні дальності до цілі дозволить покращити ефективність вирішення когерентно-імпульсними РЛС завдань за призначенням.
\end{abstract}

Ключов і слов а : радіолокаційне спостереження, когерентна пачка радіоімпульсів, фазові флуктуації, дальність до цілі, час запізнення, статистичні характеристики, достатня статистика, відношення правдоподібності, гаусівський шум.

\section{Вступ}

Постановка проблеми. Зростання маневрених можливостей сучасних аеродинамічних об'єктів обумовлює підвищення вимог до когерентноімпульсних РЛС щодо забезпечення максимальної дальності дії та необхідних точностей вимірювання координат і параметрів їх руху [1-4].

Високоточне вимірювання дальності до цілі $\epsilon$ необхідною умовою забезпечення іії радіолокаційного спостереження та стійкого супроводження. Точність вимірювання дальності до цілі в основному визначається шириною спектра зондувального сигналу РЛС, і як слід, обумовлена вибором його параметрів та закону модуляції $[2,5,6]$.

Забезпечення необхідної дальності радіолокаційного спостереження малопомітних, малорозмірних та маневруючих цілей пов'язано з отриманням якомога більшого відношення сигнал-шум на виході пристрою узгодженої обробки прийнятого сигналу. Вказане обумовлює використання когерентної пачки радіоімпульсів в якості зондувального сигналу РЛС.

Однак, умови поширення й відбиття радіолокаційного сигналу призводять до викривлення його структури та погіршення бойових можливостей РЛС. Такими умовами можна вважати: флуктуації коефіцієнта заломлення тропосфери внаслідок змін температури, тиску та вологості; інтерференцію сигналів відбитих від цілі та земної (морської) поверхні; шуми дальності внаслідок складної форми цілі [5-9].

Фазові спотворення сигналів призводять до викривлення його форми і положення максимуму (піка) тіла невизначеності у часі (результату його узгодженої часо-частотної обробки). У свою чергу, це обумовлює появу флуктуаційних помилок вимірювання дальності.

Вказане свідчить про необхідність пошуку шляхів забезпечення максимального значення відношення сигнал-шум на виході пристрою узгодженої обробки радіолокаційного сигналу та врахування його фазових викривлень при вимірюванні дальності до цілі.

Аналіз останніх досліджень і публікацій. При радіолокаційному спостереженні малорозмірних та маловисотних цілей, використання особливостей поширення радіохвиль у тропосферному радіохвильоводі дозволяє суттєво збільшити дальність дії РЛС.

Так, з урахуванням методики, викладеної у [10], результати, які наведені в роботі [11-13], вказують на те, що дальність виявлення вертольоту за межами прямої видимості в умовах його локації над морем може бути збільшена в $7 \ldots 10$ разів. Однак, при цьому виникають флуктуації фази прийнятого радіосигналу. Тому, актуальною задачею $є$ пошук шляхів оптимізації вимірювання дальності до цілі 3 урахуванням статистичних властивостей параметрів радіолокаційних сигналів.

В [14-20] показана можливість врахування фазових флуктуацій сигналів відбитих від маловисотної цілі в тропосферному хвилеводі при вимірюванні дальності до цілі. Отримано загальні вирази для оцінювання часу запізнювання та відповідної середньоквадратичної помилки, однак, без конкретизації вигляду кореляційної функції фазових флуктуацій.

Застосування наведеної методики стосовно осцилюючої кореляційної функції фазових флуктуацій 3 синтезом оптимального вимірювача часу запізнювання показано в $[12,21]$. Відмічено, що при лока- 
ції маловисотних цілей за межами дальності прямої видимості, підвищення точності вимірювання дальності в межах тропосферного радіохвилеводу за рахунок врахування флуктуацій фазової структури сигналу в порівнянні з локацією в межах дальності прямої видимості складає 3...4 рази, що свідчить про ефективність вказаної оптимізації.

Аналогічні результати відносно експонентної кореляційної функції фазових флуктуацій наведені в роботі $[3,13]$. При цьому, врахування даних флуктуацій здатне забезпечити підвищення точності вимірювання дальності у $2 \ldots 2,5$ рази.

В розглянутих роботах, в якості вхідного сигналу розглядалася реалізація набігу фази частотних складових безперервного радіолокаційного сигналу.

В дійсний час, для видачі бойової інформації засобам враження та їх наведення на цілі використовуються когерентно-імпульсні РЛС, які для радіолокаційного спостереження використовують пачкові радіосигнали.

Вказане свідчить про необхідність проведення подальших досліджень, які спрямовані на врахування статистичних характеристик флуктуацій радіоімпульсів пачкового радіосигналу в когерентноімпульсних РЛС при вимірюванні координат і параметрів руху цілей як в межах дальності прямої видимості РЛС, так й поза цими межами.

Метою статті $\epsilon$ розробка методологічних основ оптимального оцінювання дальності до цілі в когерентно-імпульсній РЛС в умовах наявності корельованих флуктуацій початкових фаз прийнятих радіоімпульсів.

\section{Основний матеріал}

Розглядається задача оптимізації вимірювання дальності до цілі в РЛС з імпульсним випромінюванням радіолокаційного сигналу. Оцінювання дальності до цілі здійснюється згідно з виразом

$$
r=t_{3} \cdot c / 2
$$

де $t_{3}$ - час запізнення прийнятого сигналу відносно зондувального; $c=3 \cdot 10^{8} \mathrm{M} / \mathrm{c}$ - швидкість поширення радіохвиль у вільному просторі.

Тобто, дальність до цілі визначається за часом запізнення, який оцінюється як аргумент максимуму відношення правдоподібності $\ell\left(t_{3}\right)$ або його натурального логарифму [2, 3, 5]

$$
\widehat{t}_{3}=\arg \max \ln \ell\left(t_{3}\right) \text {. }
$$

При прийомі когерентного сигналу з випадковою рівномірно розподіленою початковою фазою і випадковою, розподіленою за законом Релея, амплітудою на фоні некорельованого шуму, відношення правдоподібності відповідно до [2] має вид

$$
\ell=\frac{1}{1+q^{2} / 2} \exp \frac{q^{4} / 4}{1+q^{2} / 2} \rho^{2}
$$

де $q^{2}$ - відношення сигнал-шум по потужності; $\rho$ нормована функція розузгодження (ФР) спостережуваного і очікуваного радіосигналів.
В умовах регулярного вимірювання (відношення сигнал-шум по потужності $q^{2}>>1$ ) відношення правдоподібності (3) визначається виразом:

$$
\ell \approx 2 / q^{2} \cdot \exp \left(q^{2} \rho^{2} / 2\right)
$$

Нормовану часочастотну ФР можна подати у вигляді $[2,5]$

$$
\rho(\tau, F)=\frac{1}{2 E}\left|\int_{-\infty}^{\infty} \dot{U}(s) \dot{U}^{*}(s-\tau) e^{j 2 \pi F s} d s\right|,
$$

де $E$ - енергія прийнятого сигналу; $\tau=t_{3}-t_{\text {з.с }}-$ розузгодження за часом запізнення очікуваного $t_{3}$ та спостережуваного $t_{\text {з.с }}$ сигналів; $F=F_{\partial}-F_{\partial . c}-$ розузгодження за доплерівською частотою очікуваного $F_{\partial}$ та спостережуваного $F_{\partial . c}$ сигналів; $s=t-t_{\text {з.с }}-$ параметр інтегрування.

Для поодинокого прямокутного радіоімпульсу без внутрішньоімпульсної модуляції тривалістю $\tau_{i}$ вираз (5) має такий вид [2, 3]

$$
\rho(\tau, F)= \begin{cases}\left|\sin \left(\pi F\left(\tau_{i}-|\tau|\right)\right) /\left(\pi F \tau_{i}\right)\right|, & |\tau| \leq \tau_{i} / 2 \\ 0, & |\tau|>\tau_{i} / 2 .\end{cases}
$$

Вертикальний переріз даної часочастотної ФР площиною $\mathrm{F}=0$ описується виразом

$$
\rho(\tau)= \begin{cases}1-|\tau| / \tau_{i}, & |\tau| \leq \tau_{i} / 2 \\ 0, & |\tau|>\tau_{i} / 2\end{cases}
$$

і є результатом узгодженої фільтрації поодинокого радіоімпульсу.

3 наведених виразів функцій розузгодження випливає, що при використанні поодинокого радіоімпульсу, його флуктуації фази не призводять до флуктуації отриманого результату узгодженої фільтрації. Однак, використання даного сигналу має суттєві обмеження величини відношення сигнал-шум, необхідного для якісного виявлення малопомітних та малорозмірних цілей. Забезпечення стійкості радіолокаційного спостереження складних маневруючих цілей безпосередньо пов'язане з максимізацією відношення сигнал-шум, яке визначає необхідну дальності дії РЛС, якість радіолокаційного виявлення та точність вимірювання їхніх координат. Це досягається когерентним накопиченням пачки прийнятих радіоімпульсів. Однією $з$ основних тактичних характеристик РЛС є максимальна дальність виявлення, яка визначається виразом виду $[2,5]$

$$
r_{0}=\sqrt[4]{E_{3 . c} G \sigma_{u_{c e p}} A_{e \phi} /\left((4 \pi)^{2} E_{n p_{\min }}(D, F)\right)},
$$

де $E_{3 . c}$ - енергія зондувального сигналу; $G$ коефіцієнт підсилення передавальної антени; $\sigma_{u}$ середня ефективна площа розсіювання цілі; $A_{e \phi}-$ ефективна площа приймальної антени; $E_{n p_{\min }}-$ мінімальна енергія прийнятого сигналу, яка необхідна для вирішення задачі радіолокаційного спо- 
стереження; $D$ - умовна ймовірність правильного виявлення; $F$ - умовна ймовірність хибної тривоги.

При виявленні сигналу на фоні білого шуму зі спектральною густиною потужності $N_{0}$ значення $E_{n p_{\min }}(D, F)$ визначають виразом:

$$
E_{n p_{\min }}(D, F)=q^{2} N_{0} / 2=K_{p}(D, F) N_{0},
$$

де $K_{p}(D, F)=q^{2} / 2$ - коефіцієнт розрізнення.

Використання в якості зондувального сигналу РЛС пачки радіоімпульсів обумовлює необхідність коригування величини $E_{n p_{\text {min }}}(D, F)$ через зміну коефіцієнта розрізнення $K_{p}(D, F)$.

Коефіцієнт розрізнення $K_{p}(D, F)$ визначається для обраної статистичної моделі сигналу по заданих значеннях показників якості виявлення - умовної ймовірності правильного виявлення $D$ та умовної ймовірності хибної тривоги $F$.

Для моделі сигналу з випадковими амплітудою і початковою фазою умовна ймовірність правильного виявлення описується виразом [2]

$$
D=F^{1 /\left(1+q^{2} / 2\right)}
$$

і залежить тільки від відношення сигнал-шум (параметра виявлення).

На рис. 1 наведені графіки залежності умовної імовірності правильного виявлення від відношення сигнал-шум, які отримані згідно виразу (10) для наступних значень умовної імовірності хибної тривоги: $F=10^{-4}$ (крива 1), $F=10^{-6}$ (крива 2), $F=10^{-8}$ (крива 3), $F=10^{-10}$ (крива 4). Дані значення характеризують якість радіолокаційного виявлення РЛС різного призначення, як оглядових РЛС, так й РЛС супроводження.

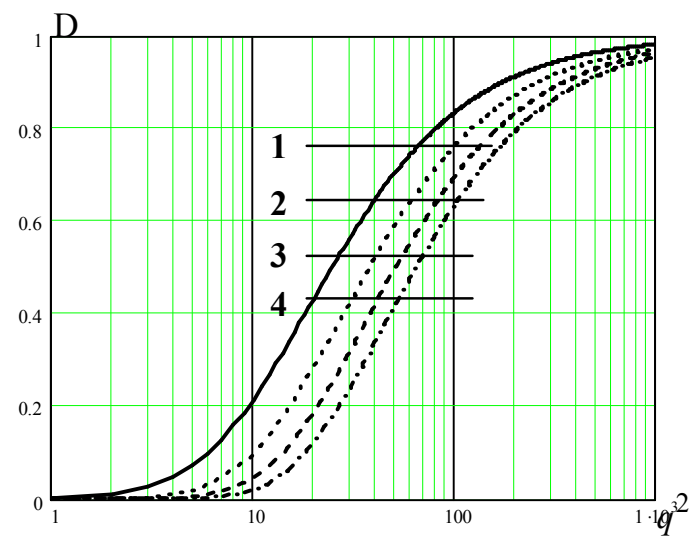

Рис. 1. Залежність умовної імовірності правильного виявлення від відношення сигнал-шум

3 наведених графіків видно, що для забезпечення стійкого радіолокаційного спостереження, значення відношення сигнал-шум по потужності повинні досягати декілька сотень, що може бути досягнуто когерентним накопиченням послідовності прийнятих радіоімпульсів. Таким чином, для підвищення умовної імовірності правильного виявлення необхідно збільшувати відношення сигнал-шум, що може бути забезпечено використанням когерентної пачки 3 якомога більшою кількістю радіоімпульсів.

При обробці когерентної пачки 3 n радіоімпульсів необхідний коефіцієнт розрізнення $K_{p_{1}}(D, F)$ одного імпульсу в пачці визначається виразом

$$
K_{p_{1}}(D, F),[\partial Б]=K_{p}(D, F),[\partial Б]-10 \lg n,
$$

Таким чином, когерентна обробка пачки n радіоімпульсів дозволяє зменшити коефіцієнт розрізнення одного радіоімпульсу згідно (11) 3 метою забезпечення заданої умовної ймовірності правильного виявлення при фіксованому значенні умовної імовірності хибної тривоги. Виграш $V$ в дальності виявлення цілі $r_{n}$ при використанні когерентної пачки 3 n радіоімпульсів у порівнянні з дальністю виявлення при використанні поодинокого радіоімпульсу $r_{0} 3$ урахуванням (7-11) визначається як

$$
V=\frac{r_{n}}{r_{0}}=\sqrt[4]{\frac{E G \sigma_{u_{c e p}} A_{e \phi}}{(4 \pi)^{2} K_{p_{1}} N_{0}}} / \sqrt[4]{\frac{E G \sigma_{u_{c e p}} A_{e \phi}}{(4 \pi)^{2} K_{p} N_{0}}}=\sqrt[4]{\frac{K_{p}}{K_{p_{1}}}} .
$$

На рис. 2 наведена залежність даного виграшу від кількості радіоімпульсів при їх когерентному накопичуванні.

Отримана залежність має зростаючий характер, що свідчить про можливість збільшення дальності дії РЛС в одиниці-десятки разів при когерентному накопиченні одиниць-десятків радіоімпульсів відповідно. При цьому, когерентне накопичення прийнятих радіоімпульсів дозволяє суттєво збільшити умовну ймовірність правильного виявлення та покращити якість радіолокаційного спостереження.

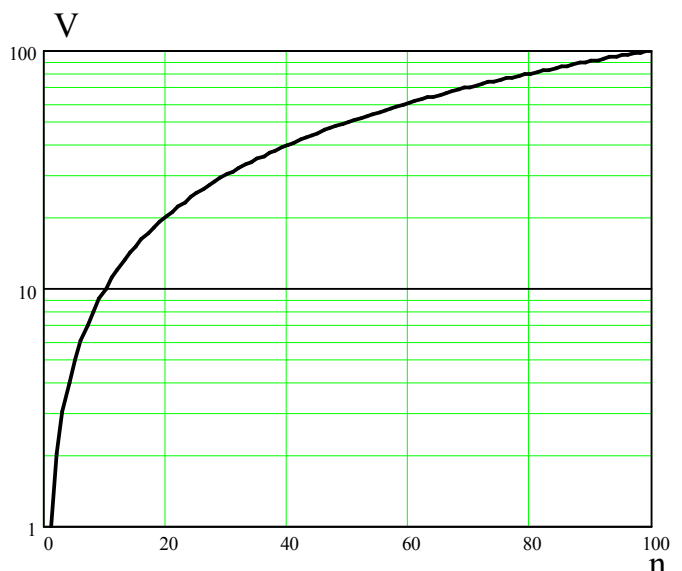

Рис. 2. Підвищення дальності виявлення цілі при когерентному накопиченні радіоімпульсів

На рис. 3 надані графіки залежності умовної імовірності правильного виявлення від кількості радіоімпульсів, що накопичуються когерентно в процесі обробки прийнятого сигналу. Результати отримані при $q^{2}==100$ для випадків, аналогічних графікам на рис. $1: F=10^{-4}$ (крива 1$), F=10^{-6}$ (крива 2), $F=10^{-8}$ (крива 3), $F=10^{-10}$ (крива 4).

Отримані залежності свідчать про те, що когерентне накопичення радіоімпульсів прийнятої пачки здатне зіначно підвищити якість радіолокаційного виявлення. При цьому, найбільший ефект спостерігається при переході від обробки одного рідіоімпульсу до когерентної обробці 10 радіоімпульсів. 


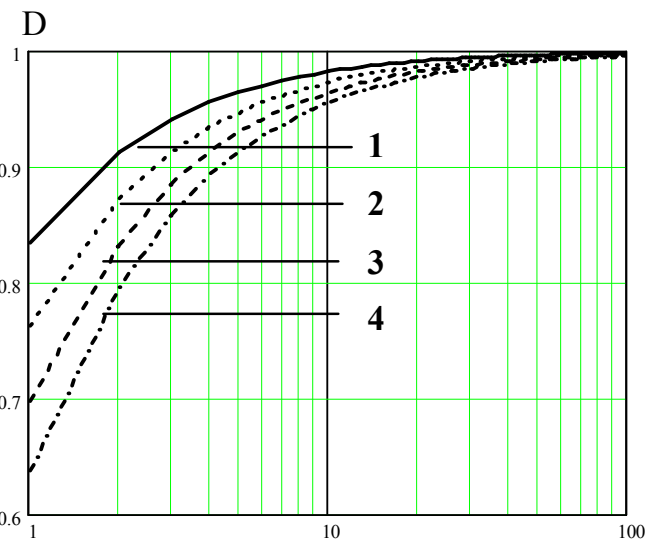

Рис. 3. Залежність умовної імовірності правильного виявлення від кількості радіоімпульсів

Підвищення умовної ймовірності правільного виявлення $D$ в залежності від умовної ймовірності хибної тривоги $F=10^{-4} \ldots 10^{-10}$ склададає $15 \ldots 30 \%$. Перехід від когерентного накопичення 10 радіоімпульсів до когерентного накопичення 100 радіоімпульсів викликає збільшення $D$ лише на $1,6 \ldots 4 \%$.

Вказане свідчить про те, що при рішенні задачі якісного радіолокаційного спостереження необхідно забезпечити синфазне складання $10 . .20$ прийнятих радіоімпульсів.

За час радіолокаційного спостереження цілі когерентно може бути оброблена лише частина із загальної кількості прийнятих радіоімпульсів внаслідок впливу реальних умов їх поширення i відбиття. Даними умовами можна вважити вплив середовища поширення радіохвиль, їх відбиття від атмосферних необнорідностей та елементів земної (водної) поверхні, а також наявності шуму дальності при радіолокаційному контакті з ціллю $[5,7]$.

У тропосфері постійно виникають складні турбулентні процеси. Флуктуації тиску, температури та вологості в неоднорідностях тропосфери призводять до флуктуацій iii показника заломлення. Внаслідок флуктуацій показника заломлення, обумовлених впливом атмосфери, виникають флуктуації фаз прийнятих радіоімпульсів, які можуть трактуватися як мультиплікативна завада. В роботі [5] показано, що тропосферні неоднорідності здійснюють суттєвий вплив на викривлення фазової структури хвиль сантиметрового діапазону. Якщо в області, суттєвою для поширення, міститься велика кількість статистично незалежних неоднорідностей, то в силу центральної граничної теореми, флуктуації фази розподілені за нормальним законом. В [5] надані величини дисперсії фазових флуктуацій радіосигналу, який пройшов тропосферу.

В тропосфері з середнім розміром турбулентних неоднорідностей $L_{0} \approx 100$ м дисперсія флуктуацій фази радіосигналу може досягати одиниць рад² для хвиль сантиметрового діапазону. При цьому, радіус кореляції фазових флуктуацій, за умовою, що вся траса поширення радіосигналу знаходиться у випадково неоднорідному середовищі, може складати сотні метрів. Згідно експериментальним і теоретичним даним в утворення фазових флуктуацій радіосигналів найбільший внесок здійснюють турбулентності тропосфери із зовнішнім масштабом від сотень метрів до одиниць кілометрів. При багатотрасовому поширенні радіохвиль частина потужності відбивається від земний або морський поверхні. Крім того радіосигнал при поширенні може відбиватися від різних метеоспотворень. Перевідбиття радіосигналу поверхнею розділу середовищ призводить до виникнення флуктуацій фази прийнятого радіосигналу $[3,4,6]$. Оскільки перевідбитий радіосигнал $є$ сукупністю сигналів від усіх таких ділянок траси, то його фазові зсуви носитимуть випадковий характер.

Реальна ціль не $є$ точковим відбивачем i, як правило, має протяжність, що значно перевищує довжину хвилі РЛС $[9,11,13]$. Під час руху такої цілі відбуваються випадкові зміни положення їі блискучих точок. Інтерференція відбитих від них радіосигналів викликає зміни амплітуди і фази результуючого прийнятого радіосигналу. Рух цілі, який включає рискання, тангаж і крен викликає шум дальності, тобто, випадкові зміни дальності різних елементів цілі відносно РЛС. Це призводить до флуктуацій радіосигналу як по фазі, так і по амплітуді, викликаючи блукання фазового центру цілі.

При відбитті сигналу від цілі з складною конфігурацією та його багатотрасовому поширенні дисперсія флуктуацій фази може досягати одиниць рад². Основна енергія флуктуацій відбитого радіосигналу зосереджена в низькочастотній області спектру - в смузі декілька Гц. При використанні пачки в даних умовах виникає суттєва втрата іiі когерентності за рахунок фазових флуктуацій іiї радіоімпульсів. Таким чином, при локації реальних цілей, особливо маловисотних та малорозмірних, вимірювання їх дальності 3 високою точністю можливе 3 максимальним врахуванням флуктуацій фаз прийнятих радіоімпульсів [9, $11,13]$. Розглядається пачка, яка має $\mathrm{n}$ радіоімпульсів з випадковою амплітудою та початковою фазою. До фаз радіоімпульсів пачки додаються флуктуаційні складові $\varphi_{i}$, які обумовлені наведеними вище умовами його поширення та відбиття.

Нормовану ФР когерентної пачки радіоімпульсів, яка входить у склад відношення правдоподібності (4), можна описати співвідношенням $[2,5]$

$$
\rho(\tau, F)=\left|\sum_{i=-M+1}^{M-1} \frac{\sin (\pi F T(M-|i|))}{M \sin \pi F T} \dot{\rho}(\tau+i \cdot T, F) e^{-j \pi i F T}\right|,
$$

де $\dot{\rho}(\tau+i \cdot T, F)$ - комплексна ФР поодинокого прямокутного радіоімпульсу; $T$ - період слідування радіоімпульсів пачки. Переріз даної ФР площиною $\mathrm{F}=0$ описується виразом

$$
\rho(\tau)=\frac{1}{n}\left|\sum_{i=0}^{n-1} \dot{\rho}_{i}(\tau+i \cdot T)\right|
$$

В даному виразі комплексна ФР поодинокого прямокутного радіоімпульсу за наявністю флуктуацій його фази має вигляд

$$
\dot{\rho}(\tau+i \cdot T)=\left(1-|\tau+i \cdot T| / \tau_{i}\right) e^{j\left[\Phi_{i}+\varphi_{i}+\Omega_{0}(\tau+i \cdot T)\right]},
$$


де $\Phi_{i}$ - фаза і-го радіоімпульсу пачки; $\varphi_{i}$ - флуктуаційна складова фази і-го радіоімпульсу пачки; $\Omega_{0}=2 \pi f_{0} ; \quad f_{0}$ - несуча частота. Квадрат даної нормованої ФР можна представити у вигляді

$$
\rho^{2}(\tau)=\frac{1}{n^{2}}\left|\sum_{i=0}^{n-1} \varsigma_{i} \exp [j \cdot x(\tau)]\right|^{2},
$$

де $\varsigma_{i}=\left(1-\frac{|\tau+i \cdot T|}{\tau_{i}}\right) ; \quad x(\tau)=\Phi_{i}+\varphi_{i}+\Omega_{0}(\tau+i \cdot T)$.

Знаходження модулю комплексного числа та узяття його квадрату дозволяє привести (14) до виду

$$
\rho^{2}(\tau)=\frac{1}{n^{2}}\left[\sum_{i=0}^{n-1} \varsigma_{i} \cos x_{i}(\tau)\right]^{2}+\left[\sum_{i=0}^{n-1} \varsigma_{i} \sin x_{i}(\tau)\right]^{2} .
$$

Враховуючи властивість квадрата суми $\left(\sum_{i=1}^{n} x_{i}\right)^{2}=\sum_{i=1}^{n} \sum_{j=1}^{n} x_{i} x_{j},(15)$ можна представити як

$$
\begin{gathered}
\rho^{2}(\Omega)=\frac{1}{n^{2}} \sum_{i=0}^{n-1} \sum_{j=0}^{n-1} \varsigma_{i} \varsigma_{j}\left[\cos x_{i}(\tau) \cos x_{j}(\tau)+\right. \\
\left.+\sin x_{i}(\tau) \sin x_{j}(\tau)\right]=\sum_{i=0}^{n-1} \sum_{j=0}^{n-1} \varsigma_{i} \varsigma_{j} \cos \left[x_{i}(\tau)-x_{j}(\tau)\right] .
\end{gathered}
$$

При малому розузгодженні спостережуваних та очікуваних значень початкових фаз радіоімпульсів пачки у даному виразі знаходиться косинус малого аргументу, для якого можна застосувати властивість $\cos x \approx 1-x^{2} / 2$, з урахуванням із (16):

$$
\rho^{2}(\tau)=\frac{1}{n^{2}} \sum_{i=0}^{n-1} \sum_{j=0}^{n-1} \varsigma_{i} \varsigma_{j} \cdot M_{i j}
$$

де $M_{i j}=1-\frac{1}{2}\left[\left(\Phi_{i}+\varphi_{i}-\Phi_{j}-\varphi_{j}\right)+\Omega_{0} T(i-j)\right]^{2}$.

Вираз (17) дозволяє отримати відношення правдоподібності (4) за наявністю фазових флуктуацій радіоімпульсів прийнятої пачки. Наявність даних складових $\varphi_{i}$ викликає необхідність переходу до усередненого відношення правдоподібності [23]

$$
\bar{\ell}=\int_{\vec{\varphi}} \ell(\vec{\varphi}) p(\vec{\varphi}) d \vec{\varphi},
$$

де $\ell(\vec{\varphi})$ - відношення правдоподібності (4) з урахуванням (17) для пачки за наявністю фазових флуктуацій іiі радіоімпульсів; $\vec{\varphi}=\left\|\varphi_{i}\right\|$ - вектор-стовпець значень флуктуаційних складових початкових фаз радіоімпульсів пачки; $p(\vec{\varphi})$ - щільність ймовірності вектора-стовпця $\vec{\varphi} ; d \vec{\varphi}=\left(d \varphi_{1} d \varphi_{2} \ldots d \varphi_{n}\right)^{T}$.

Час запізнення оцінюється як аргумент максимуму натурального логарифму усередненого відношення правдоподібності (19), як функції $t_{3}$

$$
\bar{t}_{3}=\arg \max \ln \bar{\ell}\left(t_{3}\right) \text {. }
$$

Наявність у виразі (18) випадкових складових різниць фаз радіоімпульсів пачки свідчить про не- обхідність переходу до усередненого відношення правдоподібності виду

$$
\bar{\ell}=\int_{(\Delta \vec{\varphi})} \ell(\Delta \vec{\varphi}) p(\Delta \vec{\varphi}) d \Delta \vec{\varphi},
$$

де $\vec{\varphi}=\left\|\Delta \varphi_{\kappa}\right\|$ - вектор-стовпець значень випадкових складових різниць фаз радіоімпульсів пачки; $p(\Delta \vec{\varphi})$ - закон розподілу їх щільності імовірності; $d \Delta \vec{\varphi}=d \Delta \varphi_{1} d \Delta \varphi_{2} \ldots d \Delta \varphi_{m}, \Delta \varphi \quad$ - різниця флуктуаційних складових фаз прийнятих радіоімпульсів

Вважається, що фазові флуктуації радіоімпульсів прийнятої пачки розподілені за нормальним законом с нульовим середнім, а кореляційна матриця фазових флуктуацій має наступний вид

$$
K_{\varphi}=\left\|\sigma_{\varphi}^{2} a^{|i-j|}\right\| i, j \in 1,2, \ldots, n,
$$

де $\sigma_{\varphi}^{2}$ - дисперсія фазових флуктуацій; $a$ - коефіцієнт кореляції фазових флуктуацій сусідніх радіоімпульсів пачки; $i, j$ - номери радіоімпульсів пачки.

На рис. 4 показано, що при позитивних значеннях a, зі збільшенням інтервалу між радіоімпульсами пачки кореляція убуває за експонентним законом, а при негативних значеннях а - за знакозмінним законом.

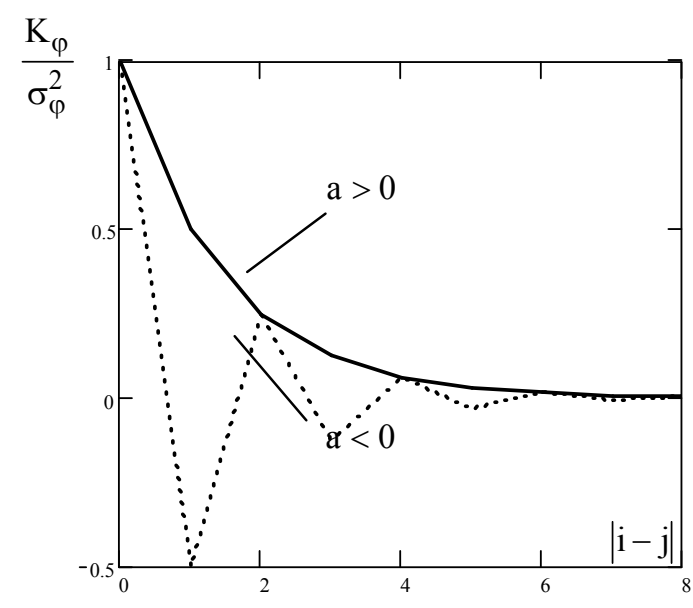

Рис. 4. Закони зміни кореляції фазових флуктуацій

Результати експерименту по визначенню статистичних характеристик радіолокаційних сигналів, відбитих від місцевих предметів за межами дальності прямої видимості при поширенні радіохвиль над морем наведені в роботі [22].

Отримані гістограми розподілу початкової фази відбитого сигналу РЛС 35Д6Д апроксимовані кривою, що відповідає нормальному закону розподілу, а нормована кореляційна функція має осцилюючий характер.

3 урахуванням цього, закон розподілу фазових флуктуацій описується виразом виду $[2,23]$ :

$$
p(\vec{\varphi})=(2 \pi)^{-\frac{n}{2}}\left|K_{\varphi}\right|^{-\frac{1}{2}} \exp \left(-\frac{1}{2} \vec{\varphi}^{T} K_{\varphi}^{-1} \vec{\varphi}\right),
$$

де $\vec{\varphi}=\left\|\varphi_{i}\right\|,(i=1,2 \ldots n)$ - вектор-стовпець значень випадкових складових фаз радіоімпульсів пачки. 
В роботі [23] показано, що щільність ймовірності $P(\Delta \vec{\varphi})$ при $m \geq 2$ визначається виразом

$$
\begin{gathered}
p(\Delta \vec{\varphi})=\frac{\sqrt{1+a}}{\left(2 \sqrt{2} \pi \sigma_{\varphi}\right)^{m}\left(1-a^{2}\right)^{m / 2}} \times \\
\times \exp \left\{-\frac{1}{4 \sigma_{\varphi}^{2}\left(1-a^{2}\right)}\left[\Delta \varphi_{m}^{2}+\left(1+a+a^{2}\right) \Delta \varphi_{1}^{2}+\right.\right. \\
\left.\left.+\left(1+a^{2}\right) \sum_{k=2}^{m-1} \Delta \varphi_{k}^{2}-2 a \sum_{k=1}^{m-1} \Delta \varphi_{k} \Delta \varphi_{k+1}\right]\right\},
\end{gathered}
$$

де $\mathrm{m}$ - кількість пар радіоімпульсів, симетричних відносно центру пачки.

Застосування виразів (4), (18) та (24) дозволяє перейти до усередненого відношення правдоподібності (21).

Отримання усередненого відношення правдоподібності $\bar{\ell}(21)$ дозволяє оцінити час запізнення $\widehat{t}_{3}(20)$ та за допомогою виразу (1) визначити дальність до цілі з врахуванням флуктуацій фаз радіоімпульсів прийнятої пачки.

\section{Висновки}

Зростання маневрених можливостей сучасних повітряних об'єктів, використання малорозмірних та малопомітних засобів повітряного нападу обумовлює істотне підвищення вимог до тактичних характеристики засобів розвідки повітряного простору, зокрема, до дальності дії РЛС.

Виконання вказаних вимог можливе при забезпеченні високих значень відношення сигнал-шум на виході пристрою оптимальної обробки радіолокаційного сигналу, що може бути реалізовано використанням в РЛС когерентної пачки радіоімпульсів.

Реальні умови виконання РЛС завдань за призначенням призводять до виникнення флуктуацій фаз радіоімпульсів прийнятої пачки, що суттєво обмежує можливості їхнього когерентного накопичення.

Врахування статистичних властивості даних флуктуацій визначає шляхи покращення якості виявлення радіолокаційного сигналу та підвищення точності вимірювання його інформативних параметрів.

\section{СПИСОК ЛІТЕРАТУРИ}

1. Довідник учасника АТО: озброєння і військова техніка Збройних Сил Російської Федерації / А.М.Алімпієв, Г.В.Пєвцов, Д.А.Гриб та ін.; за заг. ред. А.М.Алімпієва. - Х.: Оригінал, 2015. - 732 с.

2. Теория и техника обработки радиолокационной информации на фоне помех / Я.Д. Ширман, В.Н. Манжос - М: Радио и связь, 1981. $-416 \mathrm{c.}$

3. Карлов В.Д. До питання про вимірювання дальності маловисотної цілі при ії радіолокації в межах тропосферного хвилеводу над морем / В.Д. Карлов, Д.Б. Кучер, О.В. Струцінський, О.В. Лукашук // Наука і техніка Повітряних Сил Збройних Сил України. - 2016. - № 3 (24). - С. 98-101.

4. Карлов В.Д. Використання підведених радіохвилеводів для збільшення дальності виявлення маловисотних цілей над морем / В.Д. Карлов, О.В. Струцінський, К.П. Квіткін // Системи озброєння і військова техніка - 2016. № 1 (45). - С. 153-156.

5. Ширман Я.Д. Радиоэлектронные системы. Основы построения и теория. - М: 3.А.О. «МАКВИС», 1999. - 828 с.

6. Карлов В.Д. Підхід до рішення задачі оптимального виміру дальності до літака-носія високоточної зброї 3 урахуванням особливостей його локації в тропосферному радіохвилеводі / В.Д. Карлов, О.Б. Котов, Ю.Б. Ситнік, А.О.Родюков // Наука і техніка Повітряних Сил Збройних Сил України. - 2015. - № 1 (18) - С. 82-84.

7. Лобкова Л.М. Распространение радиоволн над морской поверхностью. М: Радио и связь, 1991. 256 с.

8. Карлов В.Д. Синтез вимірювача дальності маловисотної цілі над морем за межами дальності прямої видимості в умовах аномальної рефракції / В.Д. Карлов, О.П. Кондратенко, А.К. Шейгас, Ю.Б. Ситник // Системи управління, навігації та зв язку. - 2013. - № 4 (28). - С. 27-31.

9. Карлов В.Д. Оптимальне вимірювання дальності до цілі в когерентно-імпульсних РЛС шляхом врахування фазових спотворень радіолокаційного сигналу при його поширенні над морською поверхнею / В.Д. Карлов, А.М. Артеменко, О.Л. Кузнєцов // Створення та модернізація озброєння і військової техніки в сучасних умовах: зб. тез доповідей XVIII НТК ДНДІ випробувань і сертифікації озброєння та військової техніки. - Чернігів, 2018.

10. Белевщук Я.О. Розробка методики оцінки радіолокаційних характеристик вертолітної техніки Повітряних Сил Збройних Сил України / Я.О. Белевщук, М.М. Бречка, В.О. Василець, О.І. Сухаревський // Наука і техніка Повітряних Сил Збройних Сил України. - 2011. - № 1 (5) - С. 83-88.

11. Карлов В.Д. Особливості локації вертольотів в умовах поширення радіохвиль над морем / В.Д. Карлов, А.М. Артеменко, О.В. Струцінський, І.М. Пічугін // Збірник наукових праць Харківського національного університету Повітряних Сил. - 2017. - № 4 (53). - С. 93-96.

12. Карлов В.Д. Особливості локації вертольотів здійснюючих політ над морем на малих висотах / В.Д. Карлов, О.М. Бєсова, І.М. Пічугін, О.В. Струцінський // Новітні технології-для захисту повітряного простору : зб. тез доповідей 14 НК ХНУПС. 11 - 12 квітня 2018 р. - Харків, 2018. - С. 444.

13. Карлов В.Д. Особливості локації вертольотів над морем з урахуванням головного гвинта / В.Д. Карлов, А.І. Нос, I.M. Пічугін, Т.М. Курцева // Новітні технології-для захисту повітряного простору: зб. тез доповідей Тринадцятої наукової конференції Харківського національного університету Повітряних Сил імені Івана Кожедуба. 12-13 квітня 2017 р. - Харків, 2017. - С. 446.

14. Карлов В.Д. Алгоритм вимірювання дальності в автоматизованих системах наведення винищувальної авіації на маловисотну ціль над морем / В.Д. Карлов, О.Б. Котов, І.М. Пічугін, Д.В. Карлов // Системи обробки інформації. - 2015. № 10 (135). - С. 205-207.

15. Свиридов А. С., Коваленко А. А., Кучук Г. А. Метод перерозподілу пропускної здатності критичної ділянки мережі на основі удосконалення ON/OFF-моделі трафіку. Сучасні інформачійні системи. 2018. Т. 2, № 2. C. 139-144. DOI: https://doi.org/10.20998/2522-9052.2018.2.24 
16. Карлов В.Д. Особливості локації вертольотів в умовах поширення радіохвиль над морем / В.Д. Карлов, А.М. Артеменко, А.М. Коржов, О.В. Струцінський // Створення та модернізація озброєння і військової техніки в сучасних умовах: зб. тез доповідей XVIII НТК ДНДІ випробувань і сертифікації озброєння та військової техніки. - Чернігів, 2018.

17. Кучук Г.А. Минимизация загрузки каналов святи вычислительной сети / Г.А. Кучук // Системи обробки інформації. - Х.: НАНУ, ПАНМ, ХВУ, 1998. - Вип. 1(5). - С. 149-154.

18. Коваленко А. А., Кучук Г. А. Методи синтезу інформаційної та технічної структур системи управління об'єктом критичного застосування. Сучасні інформаційні системи. 2018. Т. 2, № 1. С. 22-27. DOI: https://doi.org/10.20998/2522-9052.2018.1.04

19. Кучук Г.А. Распределение каналов по трактам узла коммутации при адаптивной маршрутизации / Г.А. Кучук // Вестник НТУ «ХПИ». - Х.: НТУ «ХПИ», 2003. - № 26. - С. $167-172$.

20. Kuchuk G., Nechausov S., Kharchenko, V. Two-stage optimization of resource allocation for hybrid cloud data store. International Conference on Information and Digital Technologies. Zilina, 2015. P. 266-271. DOI: http://dx.doi.org/10.1109/DT.2015.7222982

21. Карлов В.Д. Оптимізація вимірювання дальності до цілі при їі радіолокації в межах тропосферного хвилеводу над морем. / В.Д. Карлов, А.М. Артеменко, О.В. Струцінський, І.М. Пічугін // Системи управління, навігації та зв язку. 2017. - № 5 (45). - С. 18-21.

22. Карлов В.Д. Статистичні характеристики радіолокаційних сигналів відбитих від місцевих предметів в умовах аномальної рефракції. / В.Д. Карлов, А.О.Родюков, І.М.Пічугін // Наука і техніка Повітряних Сил Збройних Сил України. - 2015. № $4(21)-$ С. 71-74.

23. Карлов В.Д. Постановка задачі оптимального оцінювання радіальної швидкості цілі при врахуванні корельованих флуктуацій початкових фаз радіоімпульсів прийнятої пачки / В.Д. Карлов, О.Л. Кузнєцов, А.М. Артеменко // Збірник наукових праць Харківського національного університету Повітряних Сил. - 2018. - № 3 (57). - С. 115-121.

Рецензент: д-р техн. наук. проф. Л.Ф. Купченко, Харківський національний університет Повітряних Сил ім. Івана Кожедуба, Харків.

Received (Надійшла) 11.04.2019

Accepted for publication (Прийнята до друку) 05.06.2019

\section{Постановка задачи оптимального измерения дальности до цели в когерентно-импульсной РЛС при учете фазовых искажений радиолокационного сигнала}

В. Д. Карлов, А. Л. Кузнецов, А. Н. Артеменко, А. Д. Карлов

В статье рассмотрены вопросы анализа возможностей обеспечения заданной дальности действия РЛС, способной осуществлять радиолокационное наблюдение малозаметных, малоразмерных и маневрирующих целей. Обоснована целесообразность использования когерентной пачки радиоимпульсов для обеспечения необходимой дальности обнаружения с заданными показателями качества. Дан сравнительный анализ возможностей использования одиночного и пачечного радиосигналов. Доказана необходимость учета коррелированных фазовых флуктуаций радиоимпульсов принятой пачки при измерении дальности до цели. Предполагается, что фазовые флуктуации распределены по нормальному закону с нулевым средним, а их корреляция убывает с увеличением интервала между радиоимпульсами пачки по экспоненциальному или знакопеременному законам. На вход приемного устройства РЛС поступают отраженные от целей сигналы на фоне некоррелированного гауссовского шума. Оценивание времени запаздывания радиолокационного сигнала осуществляется по критерию максимума натурального логарифма отношения правдоподобия, усредненного по всем возможным значениям случайных нинформативных параметров. В явном виде получено выражение нормированной функции рассогласования когерентной пачки при налички фазових флуктуаций ее радиоимпульсов. Учет фазових флуктуацій радиоимпульсов принятой пачки при измерении дальности до цели позволит улучить эффективность решения когерентно-импульсными РЛС задач по назначению.

Ключевые слова: радиолокационное наблюдение, когерентная пачка радиоимпульсов, фазовые флуктуации, дальность до цели, время запаздывания, статистические характеристики, достаточная статистика, отношение правдоподобия, гауссовский шум.

\section{Statement of the problem of optimal distance measurement to a target in a coherent pulse radar, taking into account the phase distortion of theradar signal \\ V. Karlov, O. Kuznietsov, A. Artemenko, A. Karlov}

The article deals with the analysis of the possibilities to ensure a range of a radar, that can realize radar observation of low-profile, small-sized and maneuvering targets. The expediency of using a coherent burst of radio pulses to provide the necessary detection range with specified quality indicators is substantiated. A comparative analysis of the possibilities of using single and burst radio signals is given. Proven the need, to take into account correlated phase fluctuations of the radio pulses of the pack when measuring the distance to the target. It is assumed that phase fluctuations are distributed according to the normal law with zero mean, and their correlation decreases with an increase in the interval between the radio bursts of the packet exponentially or alternatingly. Signals reflected from targets are fed to the input of the receiver against the background of uncorrelated Gaussian noise. The lag time of radio signal is estimated by the maximum criterion of the natural logarithm of the likelihood ratio, averaged over all possible values of random non-informative parameters. An explicit expression is obtained for the normalized mismatch function of a coherent packet during the presence of phase fluctuations of its radio pulses. Taking into account the phase fluctuations of the radio pulses of a taken pack when measuring the distance to the target will improve the efficiency of solving coherent-pulse radar tasks for purposes

Keywords: radar surveillance, coherent burst of radio pulses, phase fluctuations, target range, lag time, statistical characteristics, sufficient statistics, likelihood ratio, Gaussian noise. 